\title{
KANDUNGAN GIZI GONAD DAN AKTIVITAS ANTIBAKTERI EKSTRAK CANGKANG BULU BABI (Diadema setosum)
}

\section{Nutrition Content of SEA URCHIN (Diadema setosum) Gonad and Antibacteria Activities of its Shell Extracts}

\author{
Sugeng Hadinoto ${ }^{1 *}$, Ignacius Dhani Sukaryono ${ }^{1}$, dan Yessy Siahay ${ }^{2}$ \\ ${ }^{1}$ Balai Riset dan Standardisasi Industri Ambon, Jl. Kebun cengkeh, Ambon \\ ${ }_{2}^{2}$ Pasca Sarjana Universitas Pattimura Ambon Program Studi IImu Kelautan, Jl. Latumeten, Ambon \\ * Korespondensi Penulis : sugenghadin15@gmail.com
}

Diterima: 26 Februari 2017; Disetujui: 10 Juni 2017

\begin{abstract}
ABSTRAK
Diadema setosum merupakan salah satu jenis bulu babi yang mempunyai nilai ekonomis. Bagian tubuh yang dikonsumsi adalah gonadnya. Organisme ini dapat dimanfaatkan sebagai sumber pangan bergizi karena gonadnya mengandung asam amino, vitamin B kompleks, vitamin A, mineral, asam lemak omega-3, dan omega-6. Cangkang bulu babi diketahui memiliki potensi sebagai antibakteri. Penelitian ini bertujuan untuk mengetahui kandungan gizi gonad bulu babi (D. setosum) dan aktivitas antibakteri ekstrak cangkang bulu babi ( $D$. setosum). Sampel gonad $D$. setosum berasal dari perairan desa Liang, Waai dan perairan desa Sila Kabupaten Maluku Tengah sedangkan cangkang yang diekstrak diambil dari bulu babi asal desa Sila. Kandungan gizi gonad bulu babi ditentukan melalui analisis proksimat dengan metode AOAC, sedangkan aktivitas anti bakteri diuji terhadap ekstrak metanol, etil asetat dan khloroform cangkang bulu babi dengan metode difusi agar. Hasil penelitian menunjukkan bahwa gonad $D$. setosum dari ketiga lokasi penelitian tersebut berturut-turut mengandung air $(72,24 \pm 0,02 ; 71,95 \pm 0,05$ dan $77,56 \pm 0,02) \%$; abu $(11,7 \pm 0,09$ dan $11,32 \pm 0,04) \%$ bk; lemak $(3,21 \pm 0,20 ; 3,49 \pm 0,12$ dan $10,51 \pm 0,07) \%$ bk; protein $(44,8 \pm 0,36 ; 47,66 \pm 0,21$ dan $64,93 \pm 0,96) \%$ bk. Ekstrak cangkang memberikan efek antibakteri terhadap Eschericia coli, Salmonella sp. dan Bacillus cereus dengan zona hambat terhadap masing-masing bakteri dari ekstrak dengan pelarut metanol, yaitu : $(1,84 \pm 0,05 \mathrm{~mm} ; 1,84 \pm 0,03 \mathrm{~mm}$ dan $2,65 \pm 0,02 \mathrm{~mm})$; pelarut etil asetat, yaitu $(14,18 \pm 0,02 \mathrm{~mm}$; $1,65 \pm 0,03 \mathrm{~mm}$ dan $14,49 \pm 0,03 \mathrm{~mm})$; dan pelarut kloroform $(0,64 \pm 0,08 \mathrm{~mm} ; 8,98 \pm 0,03 \mathrm{~mm}$ dan $3,77 \pm 0,14 \mathrm{~mm})$.
\end{abstract}

KATAKUNCI: Diadema setosum, gonad, cangkang, kandungan gizi, antibakteri

\begin{abstract}
Diadema setosum is one species of sea urchins that have economic value. The body part of sea urchins that is commonly consumed is its gonad. This organism can be used as a source of nutritious food because it contains amino acids, vitamin B complex, vitamin A, minerals, omega3 and omega- 6 fatty acids. The shell of sea urchins also known as an antibacterial agent. This study aims to determine the nutritional content of $\underline{D}$. setosum gonad and antibacterial activity of $\underline{D}$. setosum shells extract. The sample of D. setosum gonad was collected from Liang, Waai and Sila Village waters in Central Maluku Regency. Whereas, the shells was derived from the sea urchin from Sila Village. The nutritional contents of sea urchin gonad were determined by a proximate analysis with AOAC method. The antibacterial activity was tested against methanol, ethyl acetate and chloroform extract of sea urchin shell through agar diffusion method. The results showed that the gonad of $D$. setosum from the three study sites contained of water content $(72.24 \pm 0.02$; $71.95 \pm 0.05$ and $77.56 \pm 0.02) \%$, ashes $(11.7 \pm 0.09 ; 7.34 \pm 0.14$ and $11.32 \pm 0.04) \% \mathrm{db}$, lipid ( $3.21 \pm 0.20$; $3.49 \pm 0.12$ and $10.51 \pm 0.07) \% d b$ and protein ( $44.8 \pm 0.36$; $47.66 \pm 0.21$ and $64.93 \pm 0.96$ )\%db. The shell extract showed the antibacterial effect against Escherichia coli, Salmonella sp. and Bacillus cereus the inhibition zone of each tested bacterial was different, as shown in methanol extract $(1.84 \pm 0.05 \mathrm{~mm} ; 1.84 \pm 0.03 \mathrm{~mm}$ and $2.65 \pm 0.02 \mathrm{~mm})$, ethyl acetate extract $(14.18 \pm 0.02$ $\mathrm{mm} ; 1.65 \pm 0.03 \mathrm{~mm}$ and $14.49 \pm 0.03 \mathrm{~mm})$ and chloroform extract $(0.64 \pm 0.08 \mathrm{~mm} ; 8.98 \pm 0.03 \mathrm{~mm}$ and $3.77 \pm 0.14 \mathrm{~mm}$ ).
\end{abstract}

KEYWORDS: Diadema setosum, gonad, shell, nutrient content, antibacterial 


\section{PENDAHULUAN}

Bulu babi atau yang lebih dikenal dengan nama sea urchin merupakan salah satu komoditi perikanan yang patut untuk dikembangkan pemanfaatannya sebagai bahan pangan. Bulu babi merupakan salah satu jenis biota perairan yang berasal dari filum Echinodermata. Penyebaran bulu babi terdapat hampir di seluruh zona perairan. Suwignyo, Widigdo, Wardiatno dan Krisanti (2005) menyatakan bahwa ada 950 spesies bulu babi yang tersebar di seluruh dunia. Penyebaran bulu babi di perairan Indonesia, Malaysia, Filipina, dan wilayah Australia Utara mencapai 316 jenis, sedangkan di perairan Indonesia sendiri terdapat 84 jenis bulu babi yang berasal dari 48 marga dan 21 suku (Aziz, 1993).

Diadema setosum adalah salah satu jenis bulu babi yang mempunyai nilai ekonomis (Aziz, 1993; Ratna, 2002), bagian tubuh yang dikonsumsi adalah gonad atau telurnya (Vimono, 2007). Organisme ini dapat dimanfaatkan sebagai sumber pangan bergizi (Nontji, 1993). Menurut Afifudin, Suseno, dan Jacoeb (2014), gonad bulu babi jenis $D$. setosum mengandung 18 jenis asam lemak tak jenuh, termasuk omega-3 dan omega- 6 serta 15 jenis asam amino. Asam lemak omega-3 berkhasiat untuk menurunkan kadar kolesterol di dalam darah dan mengurangi resiko terkena penyakit jantung (Almatsier, 2006). Gonad bulu babi mengandung asam amino yang cukup lengkap sebagai pemacu pertumbuhan dan kesehatan (Dincer, Cakli, Kilinc, \& Tolasa, 2010). Gonad bulu babi dapat dijadikan sebagai sumber pangan alternatif karena mengandung 28 macam asam amino, vitamin $B$ kompleks, vitamin A, mineral, asam lemak omega-3, dan omega- 6 . Sementara cangkangnya memiliki potensi sebagai antikanker, antitumor dan antimikroba (Aprillia, Pringgenies, \& Yudiati, 2012).

Bulu babi memiliki cangkang yang keras dan bagian dalamnya bersisi lima simetris. Beberapa jenis bulu babi memiliki cangkang yang dilapisi pigmen cairan hitam yang dapat digunakan untuki pewarnaan jala dan kulit. Cangkang bulu babi dapat juga dimanfaatkan untuk barang perhiasan. Limbah pengolahan bulu babi, berupa jeroan dapat diproses lebih lanjut menjadi pupuk (Ratna, 2002).

Cangkang bulu babi memiliki kandungan senyawa aktif yang bersifat toksik. Kandungan senyawa aktif dalam cangkang bulu babi telah diketahui, yaitu polihidroksi dan apelasterosida A dan B (Angka \& Suhartono, 2000). Diperkirakan racun yang ada dalam cangkang dan duri tersebut dapat digunakan sebagai bahan obat. Sebagai antimikroba, cangkang bulu babi memiliki kandungan senyawa bioaktif antara lain, serotoin, glikosida, steroid, bahan cholinergic, dan brandykinin-like substances (Dahl Jebson \& Louis,
2010), sedangkan Akerina, Nurhayati dan Suwandy (2015) melaporkan bahwa ekstrak metanol cangkang, gonad dan duri bulu babi mampu menghambat pertumbuhan bakteri E. coli. Komponen bioaktif yang terdeteksi pada gonad bulu babi adalah steroid, triterpenoid dan saponin.

Wilayah Kabupaten Maluku Tengah memiliki potensi yang tinggi sebagai penghasil bulu babi (Dinas Perhubungan, Komunikasi dan Informatika Kabupaten Maluku Tengah, 2013). Terutama di perairan Sila, Liang dan Waai Kabupaten Maluku Tengah, bulu babi di lokasi tersebut belum dimanfaatkan secara optimal, bahkan sering dibuang karena takut melukai penduduk yang ingin mencari ikan dan anak-anak yang bermain di sekitar pantai. Penelitian ini bertujuan untuk mengetahui kandungan gizi gonad bulu babi jenis $D$. setosum dari perairan Maluku Tengah dan mengetahui aktivitas antibakteri dari ekstrak cangkang bulu babi tersebut.

\section{BAHAN DAN METODE}

\section{Bahan dan Alat}

Bahan yang digunakan yaitu gonad dan cangkang bulu babi jenis $D$. setosum (Heinke \& Schultz, 2006), pelarut untuk ekstraksi cangkang yaitu metanol (Merck), etil asetat (Merck), khloroform (Merck), isolat murni Eschericia coli, Salmonella sp., Bacillus cereus yang diperloeh dari Laboratorium Teknologi Hasil Perikanan Universitas Pattimura, Tripton Soya Broth (TSB), Nutrient Broth (NB), Plate Count Agar (PCA). Alat yang digunakan antara lain oven (Memert UN110), labu kjeldhal (Buchi), alat ekstraksi sokhlet (Duran Schott), rotary vaccum evaporator, kertas saring (Whatman 42).

\section{Metode Penelitian}

\section{Prosedur Penelitian}

Penelitian ini dibagi menjadi 2 (dua) bagian, yaitu bagian pertama pengujian proksimat dari gonad bulu babi dan bagian kedua pembuatan ekstrak cangkang dan pengukuran rendemen serta uji antibakteri. Analisis proksimat menggunakan metode AOAC (2005) meliputi penentuan kadar air, kadar abu, lemak dan protein. Pada setiap sampel dilakukan 3 (tiga) kali pengulangan. Uji aktivitas antibakteri menggunakan metode difusi agar (Carson \& Riley, 1995).

\section{Pengambilan Sampel dan Analisis Proksimat Gonad Bulu Babi}

Sampel bulu babi diambil dari perairan desa Liang, Waai dan perairan Desa Sila Kabupaten Maluku 
Tengah pada saat surut terendah (pagi hari). Sampel dimasukkan ke dalam kontainer plastik, Ialu ditambahkan air laut agar sampel tetap hidup dan terjaga kesegarannya dan dibawa ke laboratorium. Setelah sampai di laboratorium dilakukan proses preparasi berdasarkan Ambarita (2003), yaitu dengan cara seluruh bagian eksternal $D$. setosum (duri, pedicellaria dan kaki tabung) dibuang dengan menggunakan gunting bedah berujung runcing. Bagian mulut/gigi (selaput peristome) dicabut dengan menggunakan pinset. Cangkang dibelah menuju bagian aboral searah dengan bagian ambulakral. Jeroan diambil dengan menggunakan pinset, dan dibuang. Gonad yang ada di dalam setengah cangkangnya dicuci dengan air laut lalu dipisahkan dari cangkangnya. Setelah itu dilakukan analisis proksimat pada gonad $D$. setosum.

\section{Ekstraksi Cangkang}

Cangkang $D$. setosum dikeringkan dengan cara diangin-anginkan ditempat gelap (tidak terkena sinar matahari) sampai kering selama kurang lebih 5 hari. Cangkang dihaluskan lalu dimaserasi dengan pelarut yang berbeda sebagai perlakuan, yaitu metanol, etil asetat dan khloroform (perbandingan 1:3 b/v) selama 3 hari. Setelah itu disaring dan diuapkan menggunakan rotary vacuum evaporator sampai diperoleh ekstrak kasar. Masing-masing ekstrak kasar kemudian dihitung rendemennya, yaitu persentase bobot ekstrak kasar terhadap bobot serbuk cangkang, dan diuji aktivitas antibakterinya.

\section{Uji Aktivitas Antibakteri (Carson dan Riley, 1995)}

Bakteri E. coli dan Salmonella sp. ditumbuhkan pada media TSB, sedangkan bakteri $B$. cereus ditumbuhkan pada media NB. Media yang digunakan untuk pengujian antibakteri adalah PCA. Sebanyak 1 $\mathrm{mL}$ kultur segar bakteri uji ditumbuhkan dalam media PCA dengan metode tuang. Setelah media memadat, lalu di atasnya diletakkan paperdisc yang telah ditetesi dengan $1 \mu \mathrm{L}$ ekstrak cangkang $D$.setosum dari masing-masing pelarut, dan diinkubasi selama 24 jam pada suhu $37^{\circ} \mathrm{C}$. Aktivitas antibakteri ditunjukkan dengan terbentuknya zona bening di sekeliling paperdisc. Diameter zona bening diukur, dinyatakan sebagai zona hambat setelah dikurangi diameter paperdisc.

\section{HASIL DAN BAHASAN}

\section{Kandungan Gizi Gonad Bulu Babi}

Komponen gizi dalam suatu bahan sangat menentukan mutu dari bahan tersebut. Informasi kandungan gizi gonad bulu babi diperoleh melalui analisis proksimat yang meliputi kadar air, kadar abu, lemak, dan protein. Hasil analisis proksimat (komposisi kimia) gonad $D$. setosum dapat dilihat pada Tabel 1.

Kadar air gonad $D$. setosum berkisar, antara $71,95 \%-77,56 \%$. Kadar air bulu babi dari ketiga lokasi

Tabel 1. Komposisi kimia gonad $D$. setosum segar

Table 1. Chemical composition of fresh gonads $\underline{D}$. setosum

\begin{tabular}{|c|c|c|c|c|c|}
\hline \multirow{2}{*}{ Komposisi/Composition } & \multicolumn{3}{|c|}{ D. setosum ${ }^{a}$} & \multirow{2}{*}{ D. setosum ${ }^{b}$} & \multirow{2}{*}{ D. setosum ${ }^{c}$} \\
\hline & $\mathbf{L}$ & $\mathbf{W}$ & $\mathbf{S}$ & & \\
\hline Air (\%)/Moisture (\%) & $72.2 \pm 0.02$ & $71.95 \pm 0.05$ & $77,56 \pm 0,015$ & 66.86 & 64.97 \\
\hline Abu (\%bk)/Ash (\%db) & $11.7 \pm 0.09$ & $7.34 \pm 0.14$ & $11.32 \pm 0.04$ & 6.31 & 7.76 \\
\hline Lemak (\%bk)/Fat (\%db) & $3.21 \pm 0.2$ & $3.49 \pm 0.12$ & $10.51 \pm 0.07$ & 20.79 & 56.32 \\
\hline Protein (\%bk)/Protein (\%db) & $44.8 \pm 0.36$ & $47.66 \pm 0.21$ & $64.93 \pm 0.96$ & 38.02 & 35 \\
\hline
\end{tabular}

Keterangan/note:

a : Hasil penelitian/Research result

b : Afifudin et al. (2014), disajikan dalam \% berat kering (bk)/Presented in \% dry base (db)

c : Akerina et al. (2015), disajikan dalam \% berat kering (bk)/Presented in \% dry base (db)

$\mathrm{L}$ : Perairan Desa Liang/Liang Village water

$S$ :Perairan Desa Sila/Sila Village water

W : Perairan Desa Waai/Waai Village water 
perairan di Maluku ini lebih tinggi jika dibandingkan dengan bulu babi dari perairan Kepulauan Seribu yang diteliti oleh Afifudin et al. (2014) dan Akerina et al. (2015) yaitu $66,86 \%$ dan $64,97 \%$. Perbedaan tersebut dapat terjadi karena beberapa faktor antara lain umur, spesies, jenis kelamin, musim penangkapan, ketersediaan pakan di air, habitat dan kondisi lingkungan (Irianto \& Soesilo, 2007). Kadar air juga menentukan masa simpan dan stabilitas suatu bahan (Isengard, 2001). Kadar air yang tinggi dapat menyebabkan bahan pangan mudah mengalami kemunduran mutu salah satunya akibat aktivitas mikroorganisme, sehingga diperlukan penanganan yang cepat dan tepat dengan mempertahankan rantai dingin.

Kadar abu gonad $D$. setosum berkisar antara (7,34-11,74)\%(bk). Hasil penelitian Afifudin et al. (2014) diperoleh kadar abu sebesar $6,31 \%$ (bk), sedangkan nilai kadar abu yang diperoleh Akerina et al. (2015) sebesar 7,76\% (bk). Adanya perbedaan kadar abu diduga karena salinitas yang berbeda pada perairan tempat pengambilan sampel, sehingga mineral yang terakumulasi dalam tubuh organisme pada perairan tersebut memiliki kadar yang berbeda pula (Purwaningsih, 2012). Walaupun diperlukan dalam jumlah sedikit, mineral juga diperlukan untuk proses metabolisme dan pertumbuhan (Hammer, Hammer, Watts, Lawrence, \& Lawrence, 2006).

Kadar lemak gonad $D$. setosum hasil penelitian, terutama dari perairan desa Liang dan Waai sangat rendah, yaitu 3,21\% (bk) dan 3,49\% (bk) dibandingkan dengan hasil penelitian Afifudin et al. (2014), yaitu $20,79 \%$ (bk) dan Akerina et al. (2015), yaitu 56,32\% (bk). Menurut Purwaningsih (2012), perbedaan kadar lemak dipengaruhi oleh tingkat kematangan gonad dan umur masing-masing spesies. Selanjutnya Purwaningsih (2012) menyatakan bahwa fase gametogenesis pada setiap spesies tidak sama, demikian pula pola makannya. McAlister dan Moran (2012) menyatakan bahwa terdapat 2 jenis sumber bahan makanan bulu babi yaitu non-planktonik yang bukan berasal dari plankton tapi berasal dari kuning telur induknya dan planktotrofik yang berasal dari fitoplankton maupun zooplankton. Ukuran gonad juga berpengaruh terhadap kandungan lemak. Gonad bulu babi yang berukuran besar secara proporsional mengandung lemak yang lebih tinggi. Kandungan lemak yang tinggi ini dapat dimanfaatkan sebagai cadangan energi untuk proses perkembangannya (Byrne, Sewell, \& Prowse, 2008). Pada penelitian ini sampel yang diambil rata-rata masih muda, memiliki gonad kecil dan belum mengalami matang gonad, sehingga kadar lemaknya rendah.

Protein merupakan komponen utama gonad bulu babi. Kadar protein gonad $D$. setosum hasil penelitian berkisar antara 44,78-64,98\% (bk), lebih tinggi dari yang pernah dilaporkan oleh Afifudin et al. (2014) dan Akerina et al. (2015). Menurut Arafa, Chouaibi, Sadok, dan El Abed (2012), kandungan protein bulu babi berhubungan dengan siklus reproduksi gonad. Selain itu seperti halnya lemak dan komposisi kimia lainnya, kandungannya dalam gonad bulu babi dipengaruhi oleh

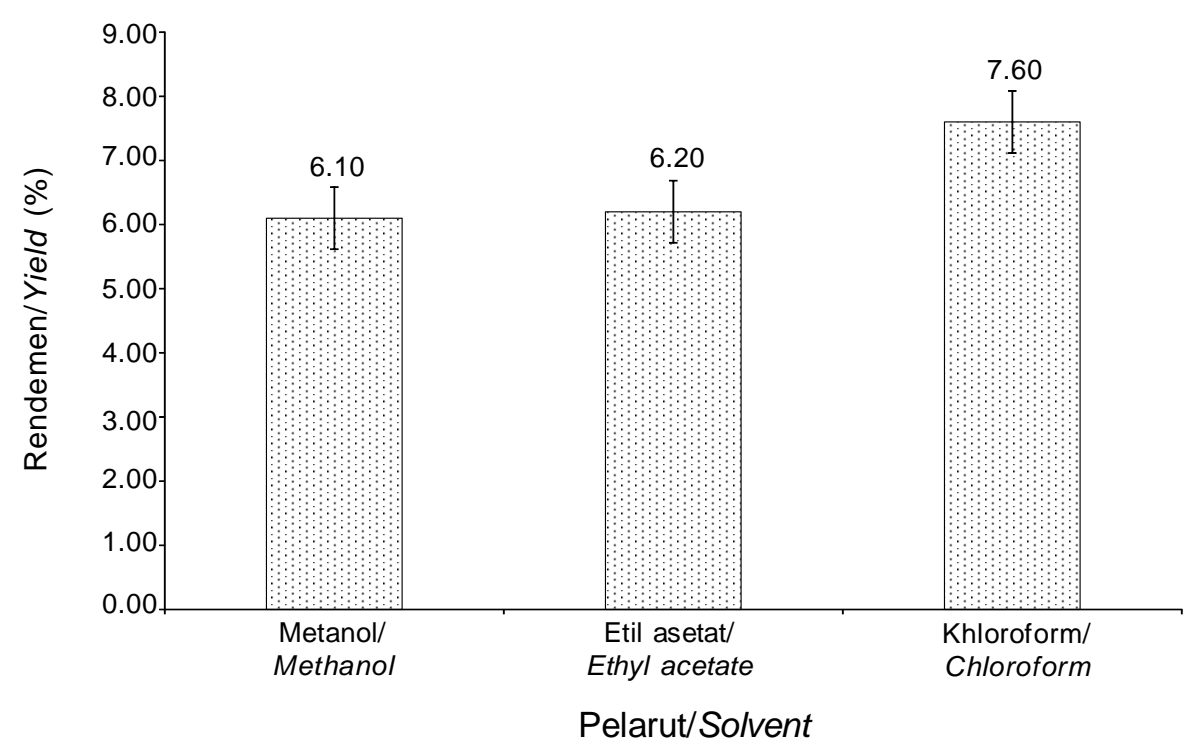

Gambar 1. Rendemen ekstrak cangkang $D$. setosum dengan pelarut yang berbeda Figure 1. The yield of extract $\underline{D}$. setosum shells in different solvent 
variasi musim, ketersediaan dan kualitas pakan, serta variasi suhu yang berkaitan dengan habitatnya.

\section{Ekstrak Cangkang Bulu Babi}

\section{Rendemen ekstrak cangkang bulu babi}

Rendemen merupakan hasil perbandingan dari bobot ekstrak dengan bobot sampel kering yang diekstraksi yang dinyatakan dalam persen. Rendemen mengindikasikan banyak sedikitnya komponen bioaktif yang mampu diekstrak oleh pelarut.

Gambar 1 menunjukkan bahwa rendemen tertinggi dihasilkan dari ekstraksi cangkang $D$. setosum menggunakan pelarut khloroform, yaitu sebesar $(7,60$ $\pm 0,3) \%$. Terjadinya perbedaan rendemen dari ekstraksi yang berbeda berkenaan dengan prinsip ekstraksi, like dissolve like yaitu pelarut polar akan melarutkan senyawa aktif yang bersifat polar dan sebaliknya pelarut non polar akan melarutkan senyawa aktif yang bersifat non polar (Khopkar, 1990). Dinyatakan pula bahwa polaritas suatu pelarut berhubungan dengan konstanta dielektriknya $(\varepsilon)$, semakin tinggi nilai $\varepsilon$ maka kepolaran suatu pelarut juga meningkat. Pelarut yang konstanta dielektriknya tinggi umumnya larut dalam air, sedangkan pelarut dengan konstanta dielektrik rendah cenderung tidak larut air. Dari ketiga pelarut yang digunakan, pelarut khloroform dan etil asetat merupakan pelarut non polar karena mempunyai nilai konstanta dielektrik masing-masing 4,8 dan 6,0.
Sedangkan metanol merupakan pelarut polar dengan konstanta dielektrik 33 (Khopkar, 1990). Dengan demikian, senyawa aktif dari cangkang bulu babi yang memiliki rendemen tertinggi dihasilkan dari senyawa non polar.

\section{Aktivitas antibakteri ekstrak cangkang bulu babi}

Hasil uji penghambatan ekstrak cangkang $D$. setosum terhadap bakteri uji disajikan pada Gambar 2. Berdasarkan zona hambatnya, diperoleh bahwa zona hambat tertinggi dari ekstrak metanol ditemukan pada $B$. cereus, dengan nilai $(2,65 \pm 0,02) \mathrm{mm}$. Akerina et al. (2015), melaporkan bahwa uji aktivitas antibakteri ekstrak metanol cangkang $D$. setosum terhadap bakteri $S$. aureus dan $E$. coli menghasilkan zona hambat masing-masing $1,25 \mathrm{~mm}$ dan $1,63 \mathrm{~mm}$. Zona hambat pada $E$. coli ini tidak jauh berbeda dengan hasil penelitian ini, yaitu zona hambat ekstrak metanol cangkang pada E.coli sebesar $1,84 \mathrm{~mm}$ (Gambar 2). Marimuthu et al. (2015) melaporkan adanya aktivitas antibakteri ekstrak metanol gonad D.setosum terhadap bakteri patogen dari Gram positif dan Gram negatif. Menurut Shankarlal, Prabu dan Natarajan (2011), terdapat senyawa bioaktif dari ekstrak metanol cangkang bulu babi dari jenis Salmacis virgulata yaitu polyhydroxy naphthoquinone yang berpotensi sebagai antibakteri maupun antioksidan. Mereka menemukan bahwa ekstrak

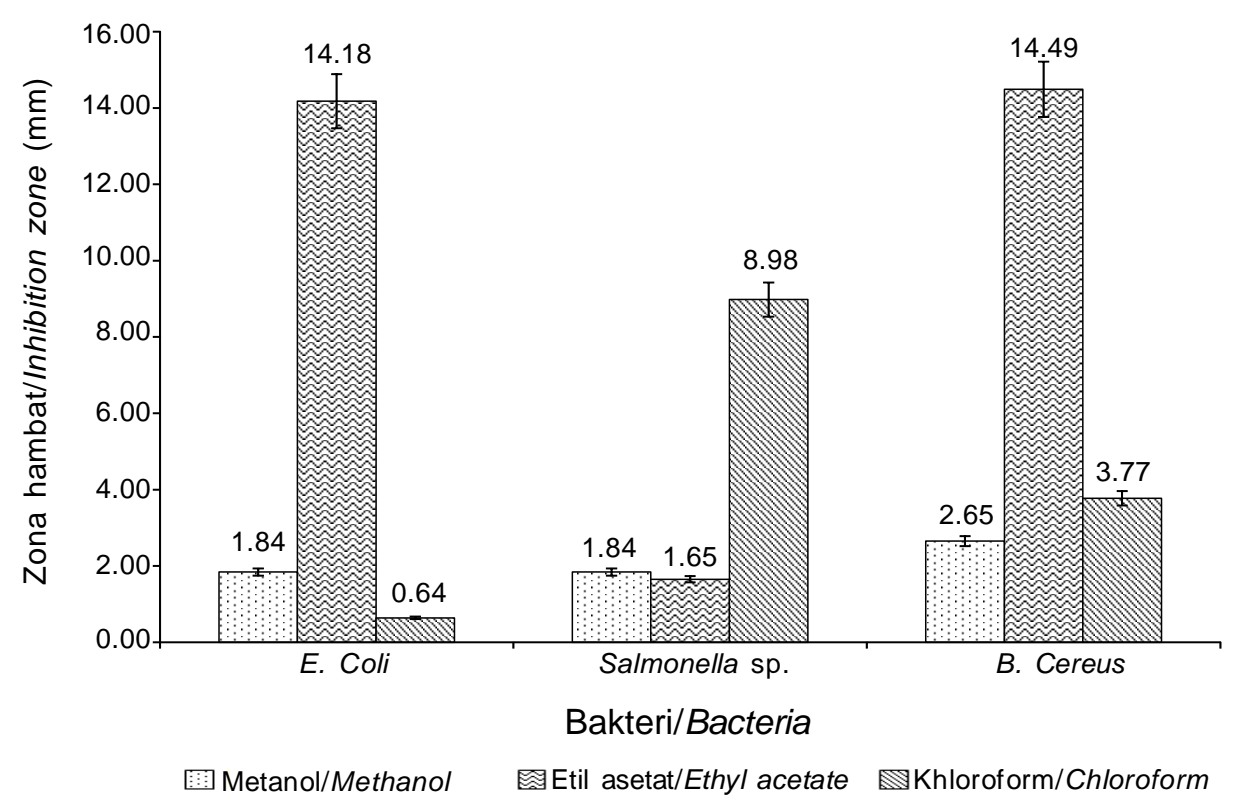

Gambar 2. Aktivitas antibakteri ekstrak cangkang D. setosum dengan pelarut metanol, etil asetat dan khloroform

Figure 2. Antibacterial activity of $\underline{D}$. setosum shells extract in methanol, ethyl acetate and chloroform solvent 
cangkang bulu babi ini mampu menghambat bakteri Vibrio cholerae dan Salmonella typhiiyang merupakan bakteri Gram negatif maupun Proteus vulgaris dan $P$. myrabilis yang merupakan bakteri Gram positif. Salah satu faktor yang mempengaruhi kemampuan menghambat bakteri dari suatu ekstrak adalah pemanasan. Proses pengeringan yang dilakukan terhadap cangkang diduga mempengaruhi aktivitas penghambatan bakteri uji. Wang dan Weller (2006) menyatakan bahwa secara umum komponen bioaktif cepat mengalami kerusakan karena sifatnya yang tidak tahan panas (thermolabile).

Hasil uji aktivitas antibakteri ekstrak etil asetat cangkang $D$. setosum menunjukkan adanya penghambatan, dengan nilai UIB yang relatif tinggi pada $E$. coli dengan zona hambat, yaitu $14,18 \pm 0,02$ $\mathrm{mm}$, dan $B$. cereus, yaitu $14,49 \pm 0,03 \mathrm{~mm}$ (Gambar 2). Etil asetat merupakan pelarut semipolar berwarna coklat kehitaman dan berbentuk pasta. Rahayu (1999) menyatakan bahwa pelarut semi polar mampu melarutkan senyawa-senyawa yang berasal dari golongan alkaloid, dan aglikon (alkoholik, fenolik, steroid, flavonoid dan saponin). Sementara, Evi (2015) menemukan bahwa fraksi etil asetat ekstrak landak laut mempunyai aktivitas anti jamur dengan zona

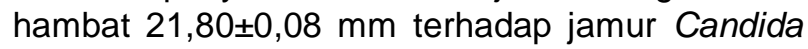
albicans.

Aktivitas anti bakteri ekstrak khloroform cangkang $D$. setosum ditemukan pada Salmonella sp., dengan zona hambat sebesar $8,98 \pm 0,03 \mathrm{~mm}$. Menurut Bragadeeswaran Kumaran, Sankar dan Prabahar (2013), senyawa yang berperan sebagai antibakteri pada ekstrak khloroform cangkang $D$. setosum adalah echinochrome A dan sponichrome. Khloroform termasuk pelarut yang bersifat semi polar dengan indeks polaritas 4,1 (Przybytek, 1984), sehingga senyawa-senyawa yang terkandung pada fraksi larut khloroform adalah senyawa-senyawa yang bersifat semi polar. Faulkner (1994) menjelaskan bahwa lipid atau lemak merupakan kelompok senyawa yang dapat larut dalam khloroform, eter atau benzena tetapi hanya sedikit larut dalam air. Salah satu senyawa lipid yaitu steroid dilaporkan terdapat pada $D$. setosum (Akerina, 2015).

Hasil di atas menunjukkan bahwa kemampuan ekstrak cangkang bulu babi dalam menghambat pertumbuhan bakteri berbeda-beda. Hal ini ditentukan oleh karakteristik serta kemampuan dari setiap bakteri dalam mempertahankan kelangsungan hidupnya. Pada penelitian yang lain, Aprillia et al. (2012) menyatakan bahwa ekstrak khloroform cangkang bulu babi ( $D$. setosum) memiliki aktivitas toksik terhadap artemia dengan nilai $\mathrm{LC}_{50}$ sebesar $133,58 \mathrm{ppm}$.

\section{KESIMPULAN}

Gonad bulu babi $D$. setosum dari perairan di Desa Sila, Liang dan Waai, Kabupaten Maluku Tengah mengandung komponen gizi yang bisa dijadikan sebagai sumber gizi alternatif. Ekstrak metanol, etil asetat maupun khloroform cangkang bulu babi ini bersifat sebagai antibakteri. Ekstrak etil asetat cangkang bulu babi lebih efektif menghambat pertumbuhan bakteri $E$. coli dan $B$. cereus dibandingkan ekstrak metanol dan ekstrak khloroform.

\section{DAFTAR PUSTAKA}

Afifudin, I.K., Suseno, S.H., \& Jacoeb, A.M. (2014). Profil Asam Lemak dan Asam Amino Gonad Bulu Babi. JPHPI., 17(1), 60-70.

Akerina, F.O., Nurhayati, T., \& Suwandy, R. (2015). Isolasi dan Karakterisasi Senyawa Antibakteri dari Bulu Babi. JPHPI., 18(1), 61-73.

Almatsier, S. (2006). Prinsip Dasar IImu Gizi. PT.Gramedia Pustaka Utama, Jakarta.

Ambarita, M.T.D. (2003). Pengaruh Kapur Sirih Terhadap Penanganan Bulu Babi dan Kualitas Gonad Bulu Babi Tripneustes gratilla (LINNAEUS) dan Echinothrix calamaris (PALLAS). Jurnal IImu dan Teknologi Pangan, 1(1), 94-105.

Angka, S. L., \& Suhartono, T. S. (2000). Bioteknologi Hasil Laut. Pusat Kajian Sumber Daya Pesisir dan Lautan. Institut Pertanian Bogor, Bogor.

(AOAC). Association of Official Analytical Chemist. Official. (2005). Method of Analysis of The Association of Official Analytical of Chemist. Arlington (US). Published by The Association of Official Analytical Chemist. Inc.

Aprillia, H. A., Pringgenies, D. \& Yudiati, E. (2012). Uji Toksisitas Ekstrak Kloroform Cangkang dan Duri Landak Laut (Diadema setosum) terhadap Mortalitas Nauplius Artemia sp. Journal of Marine Research, 1(1), 75-83.

Arafa, S. M., Chouaibi, S., Sadok, \& El Abed, A. (2012). The Influence of Season on the Gonad Index and Biochemical Composition of the Sea Urchin Paracentrotus lividus from the Golf of Tunis. The Scientific World Journal, 2012(2012), Article ID 815935, 8.

Aziz, A. (1993). Makanan dan Cara Makan Berbagai Jenis Bulu Babi. Oseana, 12(4), 91-100.

Bragadeeswaran, S., Kumaran, S. N., Sankar, P. P., \& Prabahar, R. (2013). Bioactive potential of sea urchin Temnopleurus toreumaticus from Devanampattinam, Southeast coast of India. Journal of Pharmacy and Alternative Medicine, 2(3), 9-18.

Byrne, M., Sewell, M. A., \& Prowse, T. A. A. (2008). Nutritional ecology of sea urchin larvae: influence of endogenous and exogenous nutrition on echinopluteal growth and phenotypic plasticity in Tripneustes gratilla. Functional Ecology, 22(4), 643648. 
Carson, C. F., \& Riley, T. V. (1995). Antimicrobial Activityof Major Components of The Essential Oil of Melaleuca Alternifolia. J. Appl Bacteriol, 78, 264-269.

Dahl, W. J., Jebson, P., \& Louis, D. S. (2010). Sea urchin injuries to the hand: A case report and review of the literature. The lowa Orthopaedic Journal 30, 153-156.

Dinas Perhubungan, Komunikasi dan Informatika Kabupaten Maluku Tengah. (2013). Kelautan dan Perikanan Kabupaten Maluku Tengah. http:// www.maltengkab.go.id. diakses bulan Mei 2017.

Dincer, T., Cakli, S., Kilinc, B., \& Tolasa, S. (2010). Amino Acids and Fatty Acids Composition Content of Fish Sauce. Journal of Animal and Veterinary Advances, 9(2): 311-315.

Evi, M. (2015). Pemanfaatan Ekstrak Landak Laut (Diadema setosum) Dari Pulau Lemukutan Sebagai Antijamur Candida albicans. JKK., 4(4), 61-665.

Faulkner, D. J. (1992). Biomedical Uses For Natural Marine Chemical. Oceanus, Spring. Natural Product Chemistry Journal. 29-35.

Hammer, H., Hammer, B., Watts, S., Lawrence, A., \& Lawrence, J. (2006). The effect of dietary protein and carbohydrate concentration on the biochemical composition and gametogenic condition of the sea urchin Lytechinus variegatus. Journal of Experimental Marine Biology and Ecology, 334(1),109-121.

Irianto, H. E., \& Soesilo, I. (2007). Dukungan Teknologi Penyediaan Produk Perikanan. Seminar Nasional Hari Pangan Sedunia; 2007, Nov 21; Cimanggu, Indonesia. Jakarta: Badan Riset Kelautan dan Perikanan, Departemen Kelautan dan Perikanan. 120.

Isengard, H. D. (2001). Water content, one of the most important properties of food. Food Control, 12(7):395400.

Khopkar, S. M. (1990). Konsep Dasar Kimia Analitik Penerjemah: Saptoraharjo A. UI Press, Jakarta.

Marimuthu, K., Gunaselvam, P., Aminur R. M., Xavier , R., Arockiaraj, J., Subramanian, S., Yusoff, F. M., Arshad,
A. (2015). Antibacterial activity of ovary extract from sea urchin Diadema setosum. Eur Rev Med Pharmacol Sci., 19 (10), 1895-1899

McAlister,J . S.,\& Moran,A. L. (2012). Relationships among Egg Size, Composition, and Energy: a comparative study of geminate sea urchins. Journal of Pone ,7(7), 1-9.

Nontji. (1993). Laut Nusantara. Djambatan, Jakarta.

Heinke \& Schultz P. (2006). Sea urchin, a guide to worldwide shallow water species. 3rd ed. Germany: Heinke \& Peter Schultz Scientific Publication.

Przybytek, J. T. (1984). Solvent Guide. Second Edition. Budrick@ Jackson Laboratories, Inc. 153.

Purwaningsih, S. (2012). Aktivitas Antioksidan dan Komposisi Kimia Keong Matah Merah (Cerithidea obtusa). Jurnal IImu Kelautan, 17(1), 39-38.

Rahayu, W.P. (1999). Kajian aktivitas Antimikroba Ekstrak dan Fraksi Rimpang Lengkuas (Alpinia galanga L. Swartz) Terhadap Mikroba Patogen Perusak Pangan. Disertasi. Institut Pertanian Bogor, Bogor.

Ratna, F. D. (2002). Pengaruh Penambahan Gula dan Lama Fermentasi Terhadap Mutu Pasta Fermentasi Gonad Bulu Babi (Diadema setosum) dengan Lactobacillus plalltarum Sebagai Kultur Stater. Skripsi. Institut Pertanian Bogor, Bogor.

Shankarlal, S., Prabu, K., \& Natarajan, E. (2011). Antimicrobial and Antioxidant Activity of Purple Sea Urchin Shell (Salmacis virgulata L). AmericanEurasian Journal of Scientific Research, 6(3), 178181.

Suwignyo, S., Widigdo, B., Wardiatno, Y., \& Krisanti. M. (2005). Avertebrata Air. Penebar Swadaya, Depok.

Vimono, I. B. (2007). Sekilas mengenai landak laut. Oseana, 32(3), 37-46.

Wang, L. \& Weller, C. L. (2006). Recent advances in extraction of nutraceuticals from plants. Trend in Food Science and Technology, 17, 300-312. 
JPB Kelautan dan Perikanan Vol. 12 No. 1 Tahun 2017: 71-78 